\title{
SPATIAL DIVERSITY OF THE FINANCIAL SITUATION OF COMMUNES OF THE ŚWIĘTOKRZYSKIE VOIVODSHIP IN 2007-2017
}

\author{
Paweł Dziekański', Sebastian Bobkiewicz ${ }^{2}$
}

\begin{abstract}
Actions taken at the local level should aim, among others, at: supporting development initiatives aimed at improving the quality of life of local communities, supporting the local labor market, building or improving the quality of infrastructure or the state of the natural environment. The financial situation of the commune is closely correlated with the level of local development, understood as a complex of quantitative and qualitative transformations in a given commune. The aim of the article is to analyze the spatial disproportions of the financial situation using a synthetic measure. The analysis was made in the system of rural communes of the Świętokrzyskie Voivodship. As source material, data from the Regional Accounting Chamber (Kielce branch) for 2007 and 2017 were used. The division of communes into classes of units with a similar level of the financial situation allows to state that in the high (I) classes, communes with a developed industrial function dominated, with a developing labor market, with a large number of enterprises in the SME sector, with a disappearing agricultural function. Whereas in the lowlevel class (IV), there were units with a traditional agricultural function. The values of the synthetic measure indicate a similar reaction of municipalities to changes in the economy and the spatial stability of the studied phenomenon. In 2007, the measure of the financial standing (OE) of rural communes in the Świętokrzyskie Voivodship ranged from 0.64 to 0.80 , while in 2017 from 0.56 to 0.80; TOPSIS measure in 2007 from 0.31 to 0.47 and in 2017 from 0.30 to 0.51 (TOPSIS). The financial situation was strongly correlated with own revenues, revenues from local taxes and transfers from the state budget, investment and current expenses, the balance of migration or the number of economic entities and natural persons conducting economic activity.
\end{abstract}

Key words: financial situation, municipalities, synthetic measure, Świętokrzyskie Voivodship.

JEL Classification: C38, H70, H71, H77

\section{Introduction}

Municipalities do not develop evenly, which results, among others, from unequal access to production factors as well as their quality. It should be remembered that development is the result of administration, as well as the activities of enterprises and society. The development conditions are in the local system itself. They result from resources located in a given area, economic potential and favorable environmental and spatial conditions. J. Parysek, among the commonly occurring development factors, distinguishes the needs of the community, resources and assets of the natural environment, labor resources, financial resources, existing economic potential, infrastructure resources, the local market and external markets, level of science, techniques, bilateral cooperation (Parysek, 2001).

\footnotetext{
Corresponding author:

${ }^{1}$ Jan Kochanowski University in Kielce, Poland.

E-mail: pdziekan@interia.eu

ORCID: https://orcid.org/0000-0003-4065-0043

ResearcherID: H-4658-2016

${ }^{2}$ College of Business and Entrepreneurship in Ostrowiec Świętokrzyski, Poland.

E-mail: bobkiewiczs@gmail.com

ORCID: https://orcid.org/0000-0001-8496-1375
}

Public finances are to ensure the efficiency of the entire economy. The most important categories of financing sources for municipalities in Poland are: own revenues, taxes and local fees, fees for services provided by local governments, income from assets, dividends and other capital income, rent, sale (Samuelson, Nordhaus, 2002). The financial situation is the basis for the implementation of public tasks and it determines the conditions for economic development. One of the basic problems of the functioning of local government is the limited financial resources in relation to the scope of ongoing tasks and reported investment needs (Gonet, 2013).

The financial situation is a complex phenomenon, which is influenced by many factors. Despite the difficulty of measuring it, having knowledge about the 
current state of finances of local government units is undoubtedly necessary. This knowledge allows local authorities to make comparisons with other entities and is helpful in making financial decisions. The most important feature of the financial situation is the municipality's ability to meet its own administrative and capital needs, which means maintaining and developing its own assets in line with current and future demand for public services (Hendrick, 2004).

\section{Material and research method}

The aim of the article is to analyze the spatial disproportions of the financial situation using a synthetic measure. The analysis was made in the system of rural communes of the Świętokrzyskie Voivodship. The source material was the data from the Regional Accounting Chamber (Kielce branch) for 2007 and 2017.

In the first stage of the study, variables describing the financial situation were selected. The selected set (Table 1) can be presented in the form of an observation matrix $x_{i j}$ of the form:

$$
x_{i j}=\left[\begin{array}{cccc}
x_{11} & x_{12} & \ldots & x_{1 m} \\
x_{21} & x_{22} & \ldots & x_{2 m} \\
\ldots & \ldots & \ldots & \ldots \\
x_{n 1} & x_{n 2} & \ldots & x_{n m}
\end{array}\right]
$$

where: $x_{i j}$-denotes the values of the $\mathrm{j}$-th feature for the $i$-th object $(i=1,2, \ldots, n ; j=1,2, \ldots, m)$.

From the set of variables, those characterized by low spatial variability (limit value indicator equal to 0.10 ) and high correlation of variables (according to the inverted matrix method) were removed (Malina, 2004).

The selected variables were subjected to the procedure of zero unitarization using the following formulas:

For stimulants $z_{i j}=\frac{\mathrm{x}_{i j}-\min _{i} \mathrm{x}_{i j}}{\max _{i} \mathrm{x}_{i j}-\min _{i} x_{i j}}$ when $x_{i} \in S$ (1),

For destimulants $z_{i j}=\frac{\max _{i} \mathrm{x}_{i j}-\mathrm{x}_{i j}}{\max _{i} \mathrm{x}_{i j}-\min _{i} \mathrm{x}_{i j}}$ when $x_{i} \in D(2)$,

where: $\mathrm{S}$ - stimulant, $\mathrm{D}$ - destimulant; $\mathrm{i}=1,2 \ldots \mathrm{n}$; $j=1,2 \ldots n$, xij - means the value of the $j$-th feature for the examined unit, max - the maximum value of the $\mathrm{j}$-th feature, min - the minimum value of the $\mathrm{j}$-th feature (Wysocki, Lira, 2005).

As a result of the transformation, a matrix of uniformized values of features was obtained $z_{i j}$ :

$$
z_{i j}=\left[\begin{array}{cccc}
z_{11} & z_{12} & \ldots & z_{1 m} \\
z_{21} & z_{22} & \ldots & z_{2 m} \\
\ldots & \ldots & \ldots & \ldots \\
z_{n 1} & z_{n 2} & \ldots & z_{n m}
\end{array}\right]
$$

where: $z_{i j}$ xij - the unified value.

In the next stage of the study, a synthetic measure was determined based on the TOPSIS method, taking into account the distance of the unit from the pattern $(=1)$ and antipattern $(=0)$. Then, the Euclidean distances of individual objects from the pattern and anti-pattern were determined according to the following formulas:

$$
\begin{aligned}
& d_{i}^{+}=\sqrt{\frac{1}{n} \sum_{j=1}^{m}\left(z_{i j}-z_{j}^{+}\right)^{2}} \\
& d_{i}^{-}=\sqrt{\frac{1}{n} \sum_{j=1}^{m}\left(z_{i j}-z_{j}^{-}\right)^{2}}
\end{aligned}
$$

Table 1

List of variables describing the financial situation of municipalities

\begin{tabular}{|l|c|c|}
\hline \multicolumn{1}{|c|}{ Variables } & Unit & S/D \\
\hline Budget surplus / deficit / number of inhabitants (budget solvency assessment) & PLN & S \\
\hline Interest / own income (debt service ratio) & $\%$ & D \\
\hline Operating surplus / total revenues (budget solvency ratio) & $\%$ & S \\
\hline Own income / total income (financial independence indicator) & $\%$ & S \\
\hline Share in income from PIT and CIT / number of inhabitants (fiscal wealth indicator) & PLN & S \\
\hline Income from local taxes / population (fiscal wealth indicator) & $\%$ & S \\
\hline Local tax revenue / current income (tax autonomy indicator) & $\%$ & S \\
\hline Self-financing index & $\%$ & S \\
\hline Investment expenditure / total expenditure (investment attractiveness index) & $\%$ & S \\
\hline Transfer income / number of inhabitants (state financial interference index) & $\%$ & D \\
\hline Expenditures on education and upbringing / number of inhabitants & PLN & S \\
\hline Expenditures on housing / population & PLN & S \\
\hline Health care expenditure / population & PLN & S \\
\hline Expenditures on municipal economy and environment protection / population & PLN & S \\
\hline Public safety and fire protection expenditure/ population & PLN & S \\
\hline Public administration expenditure / number of inhabitants & PLN & D \\
\hline
\end{tabular}

as - stimulant; $\mathrm{d}$ - destimulant

Source: study based on the availability of CSO BDL data, Stanny M., Strzelczyk W. 2018 Kondycja finansowa samorzadów lokalnych a rozwój społeczno-gospodarczy obszarów wiejskich; Ujęcie przestrzenne, Wydawca: Instytut Rozwoju Wsi i Rolnictwa PAN oraz Wydawnictwo Naukowe Scholar Spótka z o.o., Warszawa; Głowicka-Wołoszyn R., Wysocki F. 2014 Uwarunkowania społeczno-ekonomiczne samodzielności finansowej gmin województwa wielkopolskiego, Prace Naukowe Uniwersytetu Ekonomicznego we Wrocławiu, nr 346. 
where $\mathrm{n}$ - is the number of variables that make up the pattern or antipattern, $z_{i j}$ - means the unified value of the $j$-th feature for the unit being tested, $z_{j}^{+}, z_{j}^{-}$- means the pattern or antipattern (Wójcik-Leń, Leń, Mika, Kryszk, Kotlarz, 2019).

The synthetic measure according to the TOPSIS method for individual objects was determined on the basis of the formula:

$$
q_{i}=\frac{d_{i}^{-}}{d_{i}^{-}+d_{i}^{+}}, \text {where } 0 \leq q_{i} \leq 1, i=1,2, \ldots, n ;
$$

with: $q i \in[0 ; 1] ; \max i\{q i\}$ - the best object; $\min i\{q i\}$ - the worst object, $d_{i}^{-}$means the distance of the object from the antipattern (from 0 ), $d_{i}^{+}$means the distance of the object from the pattern (from 1). A higher value of measure indicates a better situation of the individual in the studied area (Hwang, Yoon, 1981).

Another synthetic measure was calculated according to the method based on distance in real space with the Euclidean metric according to the formula:

$$
O E_{i t}=\sqrt{\frac{1}{p} \sum_{j=1}^{p}\left(1-z_{i j t}\right)^{2}}
$$

where $i=1,2 \ldots N ; j=1,2 \ldots, p(N$ is the number of objects (poviats), ap - the number of features); zij means the value of the $j$-th feature for the given unit, $\max$ - the maximum value of the $\mathrm{j}$-th feature, $\min$ - the minimum value of the $\mathrm{j}$-th feature (Wysocki, 1996). The higher the indicator value, the worse the situation of the examined unit, the lower the indicator value, the better (Tokarski, 2005).

In the last stage, the examined area of rural communes in the Świętokrzyskie Voivodship was divided into 4 quartile groups (using the first, second and third quartiles as threshold values). The size of the indicator in the first group means a better unit, the weakest in the last one. The mutual compliance of the results obtained has been also verified based on the correlation coefficient. A scatter chart with an adjustment line for synthetic measures is also presented (Dziekański, Wyszkowski, 2018).

\section{The financial situation in theoretical terms}

The implementation of the municipality's tasks is closely related to finance. The commune performs tasks related to satisfying the needs of the local community, therefore its activities are not focused on economic profit. Finances allow for a comprehensive assessment of the operation of a local government unit and its development opportunities (Wojciechowski, 2012) or the implementation of public tasks, and determine the conditions of local economic development (Zawora, Zawora, 2014). Good financial standing is the goal of the action and the result of previous decisions and related development opportunities. It is worth noting that the analysis conducted by P. Churski, and his co-authors, and M. Stanna shows that finance is an important development factor. The indicated authors, in the research, focused on municipal self-government revenues and investment expenditure, emphasizing their significance from the point of view of the potential financing of development-oriented tasks of local governments (Stanny, Strzelczyk, 2015).

J.W. Douglas and R.K. Gaddie relate the financial situation to the state of finances within a specified period of time and the possibility of timely fulfillment of financial obligations and ensuring continuity in providing services to the local community. Emphasizing the context of limited resources in economics (including financial resources) (Douglas, Gaddie, 2002). As indicated by R. Hendrick or R. Cabaleiro-Casal et al., the financial situation cannot be described by one indicator (Cabaleiro-Casal, Buch-Gómez, Vaamonde Liste, 2013). Income and expenses, taxation and debt are a complex and multidimensional concept with different time frames related to each other, therefore, they must be analyzed and evaluated together (Hendrick, 2004).

The level of financial standing is demonstrated by, among others, ability to achieve a budget balance or increase the commune's assets. For the analysis of the financial situation, among others, there are such parameters as: the level of commune income, the financial independence of the unit, the amount of investment expenditure, the ability to obtain external financial resources, the financial result achieved by the commune (Ossowska, Ziemińska, 2010). Determinants of financial position may be shaped by the area in which the entity operates and may also be independent of it (Dziekański, 2017).

Financial decisions are the element of management because they constitute the implementation of the management right to decide or co-decide on the strategic directions and fundamental objectives of an entity and may affect its financial position. The financial condition achieved should ensure that local authorities provide services at the level desired by the inhabitants of a given unit (Groves, 1984). The financial situation of the commune is closely correlated with the level of local development, understood as a complex of quantitative and qualitative transformations in a given commune. It translates into disproportions in the possibilities of satisfying local needs (Sobczyk, 2010).

\section{Diversification of the financial situation of communes in the Świętokrzyskie Voivodship}

In 2007, the measure of the financial situation (OE) of rural communes in the Świętokrzyskie Voivodship ranged from 0.64 (Sitkówka-Nowiny, the best units) to 0.80 (Tarłów, Imielno, Słupia Konecka, Sobków, Łubnice, the weakest units), and in 2017 from 0.56 (Sitkówka-Nowiny) to 0.80 (Bliżyn). The TOPSIS measure in 2007 took values from 0.31 (Pierzchnica, the weakest unit) to 0.47 (Sitkówka-Nowiny, the best 
Table 2

Quartile groups of rural communes in the Świętokrzyskie Voivodship according to the measure of the synthetic financial situation in 2007 and 2017

\begin{tabular}{|c|c|c|c|c|c|c|c|c|}
\hline \multirow{2}{*}{ Gr } & \multicolumn{4}{|c|}{ OE financial situation } & \multicolumn{4}{|c|}{ TOPSIS financial situation } \\
\hline & Municipality & 2007 & Municipality & 2017 & Municipality & 2007 & Municipality & 2017 \\
\hline \multirow{5}{*}{ I. } & Sitkówka-Nowiny & 0.64 & Sitkówka-Nowiny & 0.56 & Sitkówka-Nowiny & 0.47 & Sitkówka-Nowiny & 0.51 \\
\hline & Smyków & 0.69 & Masłów & 0.71 & Smyków & 0.45 & Baćkowice & 0.39 \\
\hline & Wojciechowice & 0.7 & Strawczyn & 0.71 & Wojciechowice & 0.41 & Gowarczów & 0.39 \\
\hline & Wiślica & 0.71 & Baćkowice & 0.72 & Wiślica & 0.4 & Masłów & 0.39 \\
\hline & Kije & 0.72 & Miedziana Góra & 0.72 & Tuczępy & 0.39 & Michałów & 0.39 \\
\hline \multirow{5}{*}{ II. } & Bogoria & 0.75 & Bałtów & 0.76 & Obrazów & 0.38 & Bogoria & 0.36 \\
\hline & Brody & 0.75 & Bejsce & 0.76 & Łoniów & 0.38 & Kluczewsko & 0.36 \\
\hline & Łoniów & 0.75 & Bogoria & 0.76 & Zagnańsk & 0.38 & Łubnice & 0.36 \\
\hline & Rytwiany & 0.75 & Brody & 0.76 & Kije & 0.38 & Mirzec & 0.36 \\
\hline & Baćkowice & 0.76 & Lipnik & 0.76 & Rytwiany & 0.38 & Obrazów & 0.36 \\
\hline \multirow{5}{*}{ III. } & Gnojno & 0.77 & Gnojno & 0.77 & Bałtów & 0.37 & Bałtów & 0.34 \\
\hline & Samborzec & 0.77 & Górno & 0.77 & Łagów & 0.37 & Kije & 0.34 \\
\hline & Slupia & 0.77 & Iwaniska & 0.77 & Łączna & 0.37 & Nowy Korczyn & 0.34 \\
\hline & Wilczyce & 0.77 & Kije & 0.77 & Bliżyn & 0.37 & Rakow & 0.34 \\
\hline & Bieliny & 0.77 & Łoniów & 0.77 & Czarnocin & 0.36 & Rytwiany & 0.34 \\
\hline \multirow{10}{*}{ IV. } & Pawłów & 0.78 & Imielno & 0.79 & Bieliny & 0.36 & Bieliny & 0.33 \\
\hline & Radoszyce & 0.78 & Klimontów & 0.79 & Nagłowice & 0.36 & Dwikozy & 0.33 \\
\hline & Mirzec & 0.79 & Pawłów & 0.79 & Słupia & 0.36 & Imielno & 0.33 \\
\hline & Moskorzew & 0.79 & Radoszyce & 0.79 & Gnojno & 0.36 & Iwaniska & 0.33 \\
\hline & Iwaniska & 0.79 & Skarżysko Kościelne & 0.79 & Pawłów & 0.36 & Klimontów & 0.33 \\
\hline & Słupia Konecka & 0.8 & Tarłów & 0.79 & Pierzchnica & 0.31 & Bliżyn & 0.3 \\
\hline & Sobków & 0.8 & Bliżyn & 0.8 & & & & \\
\hline & Łubnice & 0.8 & & & & & & \\
\hline & Imielno & 0.8 & & & & & & \\
\hline & Tarlów & 0.8 & & & & & & \\
\hline
\end{tabular}

Source: own study based on data from RIO o / Kielce

unit) and in 2017 from 0.30 (Bliżyn) to 0.51 (SitkówkaNowiny). Regardless of the method of determining the synthetic measure, the high ones (in group I) were, among others, Sitkówka-Nowiny, Masłów, Strawczyn, Baćkowice, Miedziana Góra, Gowarczów, Michałów. The weakest group (group IV) included: Imielno, Klimontów, Pawłów, Radoszyce, Skarżysko Kościelne, Tarłów, Bliżyn, Bieliny, Dwikozy, and Iwaniska (Table 2).

Figure 1 shows the relative stability of the diversity of rural communes by the synthetic measure of the financial situation in 2017 in relation to 2007. The outlier was Sitkówka-Nowinami. The socio-economic position of the Sitkówka-Nowiny commune is related to the proximity of Kielce, the functioning of the sewage treatment plant (serving e.g. Kielce, the largest employer in the region), numerous enterprises from the small and medium sector. The unit has the character of an industrial commune with a small degree of agricultural function.

The analysis of the diversity of the measure of the synthetic financial situation indicates that in 2017, compared to 2007, the degree of diversity of communes has been relatively stable. This is evidenced by the standard deviation (0.03-0.03 OE. 0.02-0.03 TOPSIS), the classic coefficient of variation (0.04-0.04 OE, 0.06-
0.08 TOPSIS). The range values show a slight increase in diversity according to the financial situation (0.160.24 OE.0.16-0.21 TOPSIS, Table 3).

Figure 2 presents correlograms describing the relationship of the measure of synthetic financial situation calculated according to the OE and TOPSIS methods. The correlation coefficient was 0.602 (OE) and 0.622 (TOPSIS) - according to the year-to-change ratio, 0.609 (OE) and 0.567 (TOPSIS) - according to the year-to-year ratio and 0.861 (in 2007) and 0.878 (in 2017). These values indicate a similar reaction of communes to changes taking place in the economy and spatial stability of the studied phenomenon. Outliers were Sitkówka-Nowiny (with an industrial function developed) and Smyków, Wiślica, Bliżyn, Kije, Wojciechowice (with a traditional agricultural function).

Gunnar Myrdal in the theory of cumulative causation referring to the analysis of the interdependence of social, economic and institutional phenomena has proved that every element interacting with another element affects its behavior, and at the same time is modified by the reaction of that element (Stanny, Strzelczyk, 2018).

The financial situation and development were strongly correlated with own revenues, revenues from local taxes 

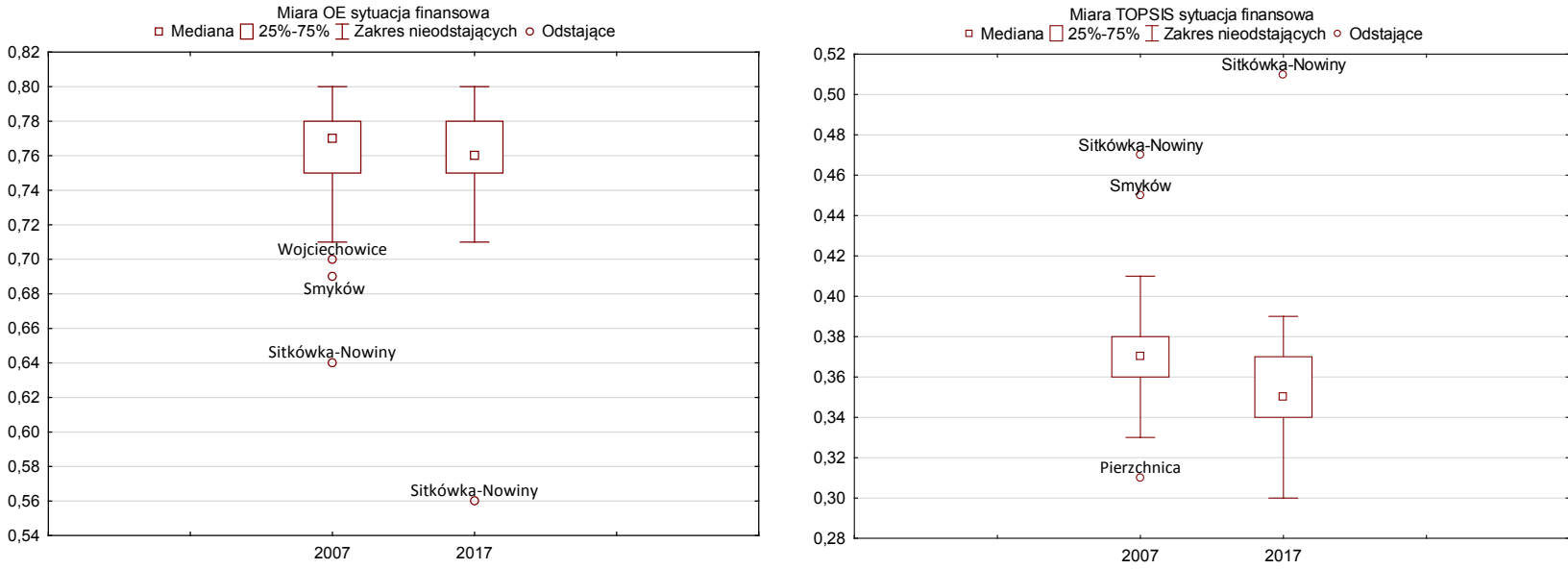

Figure 1. Dispersion of a measure of the synthetic financial situation of rural communes in the Świętokrzyskie Voivodship in 2007 and 2017

Source: own study based on data from RIO o / Kielce

and transfers from the state budget, investment and current capital expenditure (Table 4). The indicators inform about the possibility of generating income from own sources. This can be an indicator of sustainable development and allows for more flexible spending, including for investment purposes (Satoła, 2018, September). The value of the financial situation in terms of socio-economic variables was also influenced by migration, business entities and persons conducting business activity, a synthetic measure of development and entrepreneurship (Table 5).

\section{Conclusion}

The activities of communes are of a multi-criteria category. They are affected by location rents, finances, economic and infrastructural potential, natural resources, finances, entrepreneurship, etc. Rural communes of the Świętokrzyskie Voivodship have low financial potential. Disproportions in assessing the financial situation of municipalities strengthen the phenomenon of peripherality and centralization (Myrdal's core-periphery theory). The center can get rich at the expense of peripheral areas (e.g. by attracting human, finance, etc.).

The significance of economic and social factors for the fiscal situation of the surveyed rural communes of the Świętokrzyskie Voivodship is definitely smaller than it results from the research subject described so far in the literature covering the experience of other regions in this field.

Table 3

Dispersion of a measure of the synthetic financial situation of rural communes in the Świętokrzyskie Voivodship in 2007 and 2017

\begin{tabular}{|l|c|c|c|c|}
\hline & \multicolumn{2}{|c|}{ OE financial situation } & \multicolumn{2}{c|}{ TOPSIS financial situation } \\
\hline & 2007 & 2017 & 2007 & 2017 \\
\hline average & 0.76 & 0.76 & 0.37 & 0.36 \\
\hline median & 0.77 & 0.76 & 0.37 & 0.35 \\
\hline standard deviation & 0.03 & 0.03 & 0.02 & 0.03 \\
\hline quarter (quartile) deviation & 0.77 & 0.77 & 0.37 & 0.36 \\
\hline classic coefficient of variation & 0.04 & 0.04 & 0.06 & 1.00 \\
\hline positional coefficient of variation & 0.99 & 1.01 & 0.31 & 0.30 \\
\hline min & 0.64 & 0.56 & 0.47 & 0.51 \\
\hline max & 0.80 & 0.80 & 0.16 & 0.21 \\
\hline range & 0.16 & 0.24 & 0.36 & 0.34 \\
\hline quartile 1 & 0.75 & 0.75 & 0.37 & 0.35 \\
\hline quartile 2 & 0.77 & 0.76 & 0.38 & 0.37 \\
\hline quartile 3 & 0.78 & 0.78 & 1.58 & 0.03 \\
\hline quartile range & 0.03 & 0.03 & 6.43 & 2.19 \\
\hline skewness & -1.69 & -3.62 & & 11.35 \\
\hline measure of concentration-kurtosis & 5.15 & 20.69 & & \\
\hline
\end{tabular}

Source: own study based on data from RIO o / Kielce 

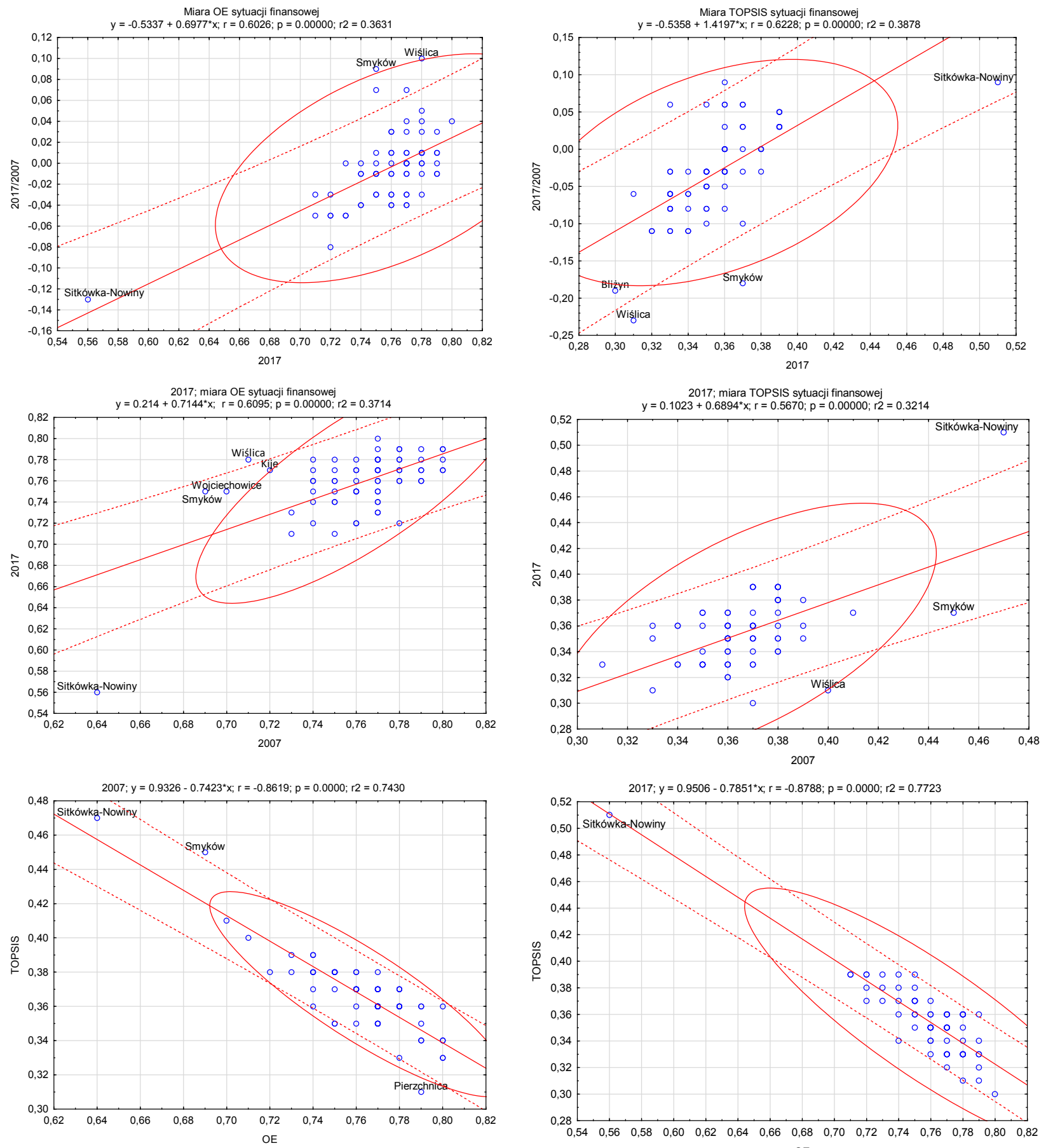

Figure 2. Map of spatial differentiation of the measure of synthetic situation and financial independence of communes of the Świętokrzyskie Voivodship in 2009 and 2018

Source: own study based on data from RIO o / Kielce

The financial situation was strongly correlated with own revenues, local tax revenues and transfers from the state budget, investment and current property expenses, migrations, business entities and persons conducting business activity, synthetic measures of development and entrepreneurship. The indicators inform about the possibility of generating income from own sources. This can be an indicator of sustainable development and allows for more flexible spending, including for investment purposes.

It seems that the main reason for the relatively small impact of economic and social conditions on the financial situation of rural communes is their strong dependence on transfer revenues transferred from the state budget. Although this situation guarantees financial security for local governments, it may also 
Vol. 6, No. 3, 2020

Table 4

Correlation between measures of financial standing and financial variables of rural communes in the Świętokrzyskie Voivodship

\begin{tabular}{|c|c|c|}
\hline & OE financial situation & TOPSIS financial situation \\
\hline TOPSIS financial situation & -0.5636 & 1 \\
\hline OE financial situation & 1 & -0.5636 \\
\hline Own income & -0.578 & 0.6307 \\
\hline Income from local taxes & -0.5754 & 0.5835 \\
\hline Income from PIT and CIT & -0.2789 & 0.0711 \\
\hline Transfer income & 0.5805 & -0.5331 \\
\hline Operating surplus & -0.2031 & 0.5054 \\
\hline Debt level & -0.0386 & -0.3479 \\
\hline Property expenses (investment) & -0.2158 & 0.4539 \\
\hline Current expenses & 0.216 & -0.4537 \\
\hline \multicolumn{3}{|l|}{ Linear correlation coefficients for observations from sample 1-207 } \\
\hline Critical value (at a double-sided $5 \%$ critical area) $=0.1364$ for $n=207$ & & \\
\hline
\end{tabular}

Source: own study based on data from RIO o / Kielce

Table 5

Correlation between measures of the financial situation and socio-economic conditions in rural communes of the Świętokrzyskie Voivodship

\begin{tabular}{|c|c|c|}
\hline & OE financial situation & TOPSIS financial situation \\
\hline Net migration rate & -0.2322 & 0.1544 \\
\hline Number of persons employed & -0.0563 & 0.039 \\
\hline Entities entered into REGON & -0.365 & 0.1328 \\
\hline Self-employed persons & -0.3223 & 0.0874 \\
\hline Number of unemployed & 0.1092 & -0.1159 \\
\hline Housing stock & 0.0668 & -0.031 \\
\hline TOPSIS development & -0.3605 & 0.1251 \\
\hline OE Development & 0.4305 & $-0,1998$ \\
\hline TOPSIS entrepreneurship & -0.4416 & 0.1777 \\
\hline OE entrepreneurship & 0.4181 & -0.1384 \\
\hline \multicolumn{3}{|l|}{ Linear correlation coefficients for observations from sample 1-207 } \\
\hline Critical value (at a double-sided 5\% critical area) $=0.1364$ for $\mathrm{n}=207$ & & \\
\hline
\end{tabular}

Source: own study based on data from RIO o / Kielce

discourage them from pursuing an active development policy in the area of using their own socio-economic potential. Low income and expenditure independence of local government units can, therefore, constitute a significant barrier to future local development.

The division of communes into classes of units with a similar level of financial standing shows that in the high level (I) classes, communes with a developed industrial function, with a growing group of enterprises (especially SMEs), located near the capital of the region (Kielce), often with vanishing agricultural function. Whereas in the low-level class (IV), there were units with a traditional agricultural function. The values of the synthetic measure and their changes indicate a similar reaction of communes to changes taking place in the economy and spatial stability of the studied phenomenon.

In 2007, the measure of the financial standing (OE) of rural communes in the Świętokrzyskie Voivodship ranged from 0.64 to 0.80 , while in 2017 from 0.56 to
0.80; TOPSIS measure in 2007 from 0.31 to 0.47 and in 2017 from 0.30 to 0.51 (TOPSIS). Regardless of the method of determining the synthetic measure, the high ones (in group I) were, among others, SitkówkaNowiny, Masłów, Strawczyn, Baćkowice, Miedziana Góra, Gowarczów, Michałów. The weakest group (group IV) included: Imielno, Klimontów, Pawłów, Radoszyce, Skarżysko Kościelne, Tarłów, Bliżyn, Bieliny, Dwikozy, and Iwaniska.

The results of the study give local governments the opportunity to compare their own financial situation with the situation of neighboring municipalities or municipalities with similar economic and social conditions. The conclusions drawn on this basis may allow local authorities to set directions for optimizing the structure of local finances. They may also be helpful for local authorities in assessing the accuracy of past decisions and the effectiveness of regional management instruments used in the past. 


\section{References:}

Aleksandrova-Zlatanska, S. K. (2019). Ocena czynników stabilności fiskalnej gmin wiejskich: przypadek Bułgarii, Problems of Agricultural Economics Zagadnienia Ekonomiki Rolnej, 3(360).

Behzadian, M., Khanmohammadi Otaghsara, S., Yazdani, M., \& Ignatius, J. (2012). A state-of the-art survey of TOPSIS applications, Expert Systems with Applications, 39(17).

Cabaleiro-Casal, R., Buch-Gómez, E. J., \& Vaamonde Liste, A. (2013). Developing a Method to Assessing the Municipal Financial Health, American Review of Public Administration, t. 43, nr 6, doi: 10.1177/0275074012451523

Churski P., Borowczak A., Dolata M., Dominik J., Hauke J., Perdał R., \& Konecka-Szydłowska, B. (2013). Czynniki rozwoju obszarów wzrostu i obszarów stagnacji gospodarczej w Polsce, Uniwersytet im. Adama Mickiewicza, Poznań.

Douglas, J. W., \& Gaddie, R. K. (2002). State rainy day funds and fiscal crises: Rainy day funds and the 1990-1991 recession revisited, Public Budgeting \& Finance, t. 22, doi: 10.1111/1540-5850.00063

Dziekański, P. (2016). Spatial Differentiation of the Financial Condition of the Świętokrzyskie Voivodship Counties, Barometr Regionalny, Tom 14 nr 3.

Dziekański, P. (2017). Diversification Synthetic Indicator For Evaluating The Financial Capacity Of Local Government. The Case Of Polish Voivodships. Acta Universitatis Agriculturae Et Silviculturae Mendelianae Brunensis; Volume 65 Number 2, doi: 10.11118/actaun201765020611

Dziekański, P., \& Wyszkowski, A. (2018). Ocena przestrzennego zróżnicowania sytuacji finansowej gmin województwa świętokrzyskiego z wykorzystaniem miary syntetycznej, Optimum. Economic Studies, no. 1(91).

Gonet, W. (2013). Naprawa finansów jednostki samorządu terytorialnego, Difin, Warszawa.

Groves, S. M. (1984). An introduction to Evaluating Financial Condition, In: J. Matzer, Practical Financial Management. New Techniques for local Government. Washington: ICMA.

Hendrick, R. (2004). Assessing and measuring the fiscal health of local government: Focus on Chicago suburban municipalities, Urban Affairs Review, vol. 40, nr 1.

Hendrick, R. (2004). Assessing and measuring the fiscal health of local governments, Urban Affaires Review, t. 40, nr 1, doi: $10.1177 / 1078087404268076$

Hwang, C. L., \& Yoon, K. (1981). Multiple attribute decision making. Methods and applications, Springer, Berlin, For: A. Bieniasz, Z. Gołaś, A. Łuczak, 2013, Zróżnicowanie kondycji finansowej gospodarstw rolnych wyspecjalizowanych $w$ chowie owiec i kóz w krajach Unii Europejskiej, Roczniki Ekonomii Rolnictwa i Rozwoju Obszarów Wiejskich, T. 100, z. 1.

Kukuła, K. (2000). Metoda unitaryzacji zerowanej, PWN, Warszawa.

Malina, A. (2004). Wielowymiarowa analiza przestrzennego zróżnicowania struktury gospodarki Polski wedtug województw, Wyd. Akademii Ekonomicznej w Krakowie, Kraków 2004.

Młodak, A. (2006). Analiza taksonomiczna $w$ statystyce regionalnej, Centrum Doradztwa i Informacji Difin, Warszawa.

Nowak, E. (1990). Metody taksonomiczne w klasyfikacji obiektów społeczno-gospodarczych, PWE, Warszawa.

Ossowska, L., \& Ziemińska, A. (2010). Kondycja finansowa gmin wiejskich i miejsko-wiejskich województwa pomorskiego, Journal of Agribusiness and Rural Development 4(18).

Parysek, J. J. (2001). Podstawy gospodarki lokalnej, Wydawnictwo Naukowe UAM, Poznań.

Pietrzak, M. B. (2016). The problem of the inclusion of spatial dependence within the TOPSIS Method. Montenegrin Journal of Economics, 12(3).

Samuelson, P., \& Nordhaus, W. (2002). Ekonomia, Wydawnictwo Naukowe PWN, Warszawa.

Satola, Ł. (2018, September). Municipal infrastructure and the Level of Fiscalism in Local Taxes. In: Proceedings of the International Scientific Conference "Economic Sciences for Agribusiness and Rural Economy" (No. 1), pp. 370-375. doi: 10.22630/ESARE.2018.1.52

Sobczyk, A. (2010). Rozwój lokalny - wybrane problemy finansowania, Zeszyty Naukowe SGGW, Ekonomika i Organizacja Gospodarki Żywnościowej 81, Warszawa.

Stanny, M., \& Strzelczyk, W. (2015). Zróżnicowanie przestrzenne sytuacji dochodowej gmin a rozwój społecznogospodarczy obszarów wiejskich w Polsce, Stowarzyszenie Ekonomistów Rolnictwa i Agrobiznesu Roczniki Naukowe, tom XVII, zeszyt 4.

Stanny, M., \& Strzelczyk, W. (2018). Kondycja finansowa samorządów lokalnych a rozwój społeczno-gospodarczy obszarów wiejskich; Ujęcie przestrzenne, Wydawca: Instytut Rozwoju Wsi i Rolnictwa PAN oraz Wydawnictwo Naukowe Scholar Spółka z o.o., Warszawa.

Tokarski, T. (2005). Statystyczna analiza regionalnego zróżnicowania wydajności, zatrudnienia i bezrobocia $w$ Polsce, Wydawnictwo PTE, Warszawa.

Ustawa z dnia 13 listopada 2003 roku o dochodach jednostek samorzadu terytorialnego, art. 4 (Journal of Laws No. 203. item 1966).

Wakuła, M. (2018). Klasyfikacja gmin podregionu ostrołęcko-siedleckiego ze względu na ich kondycje finansowa, Wiadomości statystyczne Rok LXIII 7 (686).

Wojciechowski, E. (2012). Zarządzanie w samorządzie terytorialnym, Warszawa. 
Wójcik-Leń, J., Leń, P., Mika, M., Kryszk, H., \& Kotlarz, P. (2019). Studies regarding correct selection of statistical methods for the needs of increasing the efficiency of identification of land for consolidation - A case study in Poland. Land Use Policy.

Wysocki, F. (1996). Metody statystycznej analizy wielowymiarowej w rozpoznawaniu typów struktury przestrzennej rolnictwa, Roczniki AR w Poznaniu, seria: Rozprawy Naukowe, z. 266, Poznań.

Wysocki, F., \& Lira, J. (2005). Statystyka opisowa, Wyd. AR, Poznań.

Zalewski, W. (2012). Zastosowanie metody TOPSIS do oceny kondycji finansowej spótek dystrybucyjnych energii elektrycznej, Ekonomia i Zarządzanie, 4.

Zawora, J., \& Zawora, P. (2014). Stan finansów samorządowych u progu nowej perspektywy finansowej Unii Europejskiej na lata 2014-2020, Przedsiębiorstwo i Region, nr 6.

Zeliaś, A., \& Malina, A. (1997). O budowie taksonomicznej miary jakości życia. Syntetyczna miara rozwoju jest narzędziem statystycznej analizy porównawczej, Taksonomia z. 4. 